\title{
INVESTIGATIONS ON MACROZOOBENTHOS IN LAKE GREVELINGEN, WITH SPECIAL EMPHASIS ON THE ROLE OF POLYCHAETES (V).
}

\author{
R.H.D. LAMBECK \\ (Delta Institute for Hydrobiological Research, Yerseke, The Netherlands)
}

\section{SUMMARY}

An outline has been given of the soft-bottom macrozoobenthic research in Lake Grevelingen, after its creation in 1971. A faunistic study aims at assessing the effect of the closure of the former estuary on the species composition, diversity, and distribution of the benthic macrofauna. The main project is a study into the biomass and production of the macrozoobenthos, in order to estimate its role in the carbon cycle in the lake.

As regards the faunistic work, a preliminary "species-balance" has been presented for molluscs and polychaetes. The total number of mollusc species hardly changed after the closure, the number of polychaetes decreased with about one quarter. Nearly all "disappeared" species were rare or rather scarce in the Grevelingen estuary and most of them may be regarded as typical North Sea species. Several newcomers have also been recorded after the closure. The strong river influence in the former estuary causing wide salinity fluctuations, possibly selected for more hardy species, and these species obviously are able to survive quite well in the present brackish lake.

Mean mollusc biomass in April decreased in the first years after the closure. In 1973 it amounted to only $11 \mathrm{~g}$ ash-free dry weight. $\mathrm{m}^{-2}$. In view of the preliminary estimate for 1977 (over $50 \mathrm{~g}$ ash-free dry weight. $\mathrm{m}^{-2}$ ) a recovery has taken place.

Up till 1976 polychaete biomasses were assumed to be unimportant in Lake Grevelingen, reason to ignore them in benthic production studies. A survey with a Van Veen bottom grab seemed to confirm this: mean April biomass in 1977 was only $2.6 \mathrm{~g}$ ash-free dry weight. $\mathrm{m}^{-2}$. However, especially in coarser sediments this bottom grab inadequately samples the bottom fauna. Diver-taken cores proved that, on average, polychaetes live deeper than molluscs and are relatively much more underestimated with the Van Veen grab. Moreover, sieving techniques used are not appropriate for many of the fragile polychaete species. In a special polychaete research at three permanent stations a mean annual biomass of 7.5-12.4 g ash-free dry weight was estimated. Mainly based on P/B ratios from the literature a conservative production estimate for these three stations gave values of $16-25 \mathrm{~g}$ ash-free dry weight. $\mathrm{m}^{-2} . \mathrm{yr}^{1}$. This indicates an important role for polychaetes in the benthic ecosystem of Lake Grevelingen.

\section{THE AEROBIC MINERALIZATION OF ORGANIC COMPOUNDS IN THE SALINE LAKE GREVELINGEN (THE NETHERLANDS) (VI).}

\author{
A.B.J. SEPERS \\ (Delta Institute for Hydrobiological Research, Yerseke, The Netherlands)
}

SUMMARY

During a one year period the uptake of aspartic acid and of a mixture of amino acids 